Doi: https://doi.org/10.17398/2340-4256.16.243

\title{
TERMINOLOGICAL CONSIDERATIONS OF RELIGIOUS EDUCATION IN POLAND
}

\author{
CONSIDERACIONES TERMINOLÓGICAS SOBRE LA \\ EDUCACIÓN RELIGIOSA EN POLONIA
}

\author{
WOJCIECH CICHOSZ \\ Nicolaus Copernicus University
}

Recibido: 07/07/2020

Aceptado: 23/09/2020

\begin{abstract}
Ancient civilization associated upbringing with culture, which later accepted Christianity. In Latin culture - arising from three sources: Greek philosophy, Roman law and the Christian religion (Acropolis, Quirinal and Golgotha) - pedagogics is understood as a theory of upbringing and teaching, being a conscious and purposeful education activity, but pedagogy is rather a system and whole activities: skills and educational effects. In the XXIst century, those matters that were understood to be a firm, binding basic belief held by all not long ago, have today become a subject of social discussion. More and more frequently, the general theory of a sign has been shaken up (semiotics). Language has started to lose, from the speed of continual geometry, its prime and fundamental purpose which is interpersonal communication. Terms and words, even on a scientific level (sometimes in the name of that same science) are used with different meanings (semantics), mutual references (syntax) and contexts (denotations and connotations). With this in mind, it is worth taking up the subject of basic concepts in the field of pedagogy, upbringing and religious education. How then do we understand pedagogics from pedagogy, religious education from catechetics and how they interact (dependences)? In view of the above, it can be stated that pedagogics will as a rule be question-orientated - which one? (philosophical and anthropological scientific
\end{abstract}


reflection on upbringing especially at a theoretical level), and pedagogy on the question whose? (it is about both the person and the practice of integral interaction).

Keywords: Paidea, Pedagogy, Pedagogics, Upbringing, Religious Education, Pedagogics of Religion, Catechesis.

\section{RESUMEN}

La civilización antigua asociaba la educación con la cultura, que posteriormente aceptó el cristianismo. En la cultura latina -que surge de tres fuentes: La filosofía griega, el derecho romano y la religión cristiana (Acrópolis, Quirinal y Gólgota) - la pedagogía se entiende como una teoría de la crianza y la enseñanza, siendo una actividad educativa consciente y propositiva, pero la pedagogía es más bien un sistema y un conjunto de actividades: competencias y efectos educativos. En el siglo XXI, lo que hasta hace poco se entendía como una creencia básica firme y vinculante, se ha convertido hoy en un tema de discusión social. Cada vez con más frecuencia, la teoría general del signo se ha visto sacudida (semiótica). El lenguaje ha empezado a perder, a partir de la velocidad de la geometría continua, su finalidad primera y fundamental que es la comunicación interpersonal. Los términos y las palabras, incluso en el plano científico (a veces en nombre de esa misma ciencia) se utilizan con significados (semántica), referencias mutuas (sintaxis) y contextos (denotaciones y connotaciones) diferentes. Teniendo esto en cuenta, vale la pena retomar el tema de los conceptos básicos en el ámbito de la pedagogía, la crianza y la educación religiosa. ¿Cómo entender entonces la pedagogía desde la pedagogía, la educación religiosa desde la catequesis y cómo interactúan (dependencias)? Teniendo en cuenta lo anterior, se puede afirmar que la pedagogía se orientará, por regla general, a la pregunta ¿cuáles? (reflexión científica filosófica y antropológica sobre la educación, especialmente a nivel teórico), y la pedagogía a la pregunta ¿de quién? (se trata tanto de la persona como de la práctica de la interacción integral).

Palabras clave: Paidea, Pedagogía, Pedagogía, Crianza, Educación religiosa, Pedagogía de la religión, Catequesis.

Since ancient Greek times, Man appears on the pages of history as an entity that both knows and formulates judgements. The first scholars postulated that a person should not only watch the world (the experience sphere) but should also get to know it (the intellectual sphere). Their conviction was that a wise man is not that individual who "gazes" upon his surrounding reality but he who knows rational answers to the basic questions of Man's existence: Who am I? Where did 
I come from and where am I heading? Current teaching and technological development have led to a post-industrial age, and the effects of globalization have created a new world order (New World Order and Technetronic Society) ${ }^{1}$. In the XXIst century, those matters that were understood to be a firm, binding basic belief held by all not long ago, have today become a subject of social discussion. On the one hand, positions have become polarised and, on the other, relativization of concepts can be observed together with a progressive axiological blur ${ }^{2}$. More and more frequently, the general theory of a sign has been shaken up (semiotics). Language has started to lose, from the speed of continual geometry, its prime and fundamental purpose which is interpersonal communication. Terms and words, even on a scientific level (sometimes in the name of that same science) are used with different meanings (semantics), mutual references (syntax) and contexts (denotations and connotations). With this in mind, it is worth taking up the subject of basic concepts in the field of pedagogy, upbringing and religious education ${ }^{3}$. To attempt to systematize concepts seems most advisable.

\section{BASIC CONCEPTS IN THE FIELD OF EDUCATION}

Ongoing scientific discussions are increasingly thought necessary because of the growing awareness of disruptions in the sphere of education and upbringing. Hence many authors raise this important social issue. Upbringing is changed in all possible cases. Conversations and research are not limited to the descriptive and the predictive (predicting the course of phenomena and processes), but they are introduced into the explanatory sphere, when we get to know about the causes and explains interactions (dependencies). This principle applies to analysed concepts in the field of pedagogy and pedagogics. Despite the extraordinary development of modern humanities, many authors still do not distinguish between these two basic concepts, because although they refer to the same research area and are closely connected, they are not the same etymologically or in terms of

1 Zbigniew Brzezinski, Between Two Ages (New York: The Viking Press 1970, 9: “The postindustrial society is becoming a technetronic society: a society that is shaped culturally, psychologically, socially and economically by the impact of technology and electronics - particularly in the area of computers and communications"; Wojciech Cichosz, "Quo vadis Akademia? Kulturowa rekonfiguracja nauki”, Studia Gdańskie 38 (2016): 201-213.

2 Comp. W. Cichosz, Wychowanie integralne : praktyczna recepcja gimnazjum w Zespole Szkót Katolickich im. św. Jana Pawła II w Gdyni 1992-2019 (Pelplin: Bernardinum 2019), 86-87.

3 Comp. idem, "Pedagogia czy pedagogika? Recepcja aksjologii terminologicznej", en Pedagogika rodziny : podejście systemowe. Vol. 1: Familiologia, ed. Marek Marczewski et al. (Gdańsk: Wyższa Szkoła Społeczno-Ekonomiczna 2016), 123-140; Education of tomorrow : contemporary education and is contexts, ed. Kazimierz Denek (Sosnowiec: Wyższa Szkoła Humanitas 2011). 
content. The result is that we continue "to use the same words and make use of the same signs and yet we do not understand one another"4.

According to the assessment of the state of contemporary culture, it is extremely important to correctly and wisely apply the proper methodology and approach used as general principles of scientific conduct for everybody equally, and also for those who are engaged in education ${ }^{5}$. They should try to establish its nature, direction, aims and opinions. Specifying the terms seems to be the key and is absolutely essential, as referring to specific concepts significantly influences the shape of ongoing debates. Not only do serious mistakes in the field of semiotics (the general theory of signs) result in confused terminology - sometimes even small, subtle differences decide about the correct scientific proceedings and educational practices. How then do we understand pedagogics (Gr. $\pi \alpha l \delta \alpha \gamma \omega \gamma l \kappa \eta$ - paidagogike) from pedagogy (Gr. $\pi \alpha l \delta \varepsilon i \alpha, \pi \alpha l \delta \alpha \gamma \omega \gamma i \alpha$ - paideia, pedagogia, Lt. educatio, ars educandi), religious education from catechetics and how they interact (dependences)?

\section{PEdAGOGICS AND PEDAGOGY}

The starting point analysing semantic-syntatic terms relating to education and upbringing - referring to the areas of social science and humanities, pedagogics or theology - is the long and very rich Hellenic tradition which dates back to the turn of the seventh/sixth centuries BC. Fundamentally, there are two basic nouns in the pedagogical language: pedagogics and pedagogy. Etymologically speaking, they respectively come from the Greek source of paidagogike (Gr. $\pi \alpha l \delta \alpha \gamma \omega \gamma \imath \kappa \eta$ ), which in turn derives from the words pais, genitive paidos (Gr. $\pi \alpha \tilde{l} \varsigma, \pi \alpha l \delta o ́ \varsigma-$ boy; child; descendant; offspring) as well as ago (Gr. $\ddot{\alpha} \gamma \omega$ - I lead someone, something; the participle agagos - the leader), also to the ancient paidei (Gr. $\pi \alpha$ l $\delta \varepsilon i \alpha)$. The Greek term paideia (also occurs - paidea) referred to all actions in the field of exercise and upbringing. Next to it paidagogos (Gr. $\pi \alpha l \delta \alpha \gamma \omega \gamma o ́ s$, Lt. paedagogus, pedagogus - leading a child) there also appears the word paideutes, which is the teacher exercising and disciplining the pupil. Initally, the idea of education (the model that was accepted by society) concentrated on a gymnastics education (the Dorian model of education which was also known as Spartan). With the passing

4 Wojciech Cichosz, Metodologia : elementarz Studenta (Gdańsk: Zakłady Graficzne im. KEN SA 2000), 7. Comp. idem, Wychowanie chrześcijańskie wobec postmodernistycznej prowokacji (Gdańsk: Zakłady Graficzne im. KEN SA 2001), 12; Idem, Pedagogia wiary we wspótczesnej szkole katolickiej (Warszawa: Wydawnictwo TYPO2 2010), 31; Idem, Możliwości dialogu wychowania chrześcijańskiego ze wspótczesna edukacja polska (Pelplin: Bernardinum 2013), 21.

5 Comp. Lluis Oviedo-Torró, "Meaning and Religion: Exploring Mutual Implications", Scientia et Fides 7(1) (2019): 25-46. 
of time and with the philophical shaping and development of culture, there was a transition to the so-called Athenian model (lonic).

The development of the pedagogical tradition meant that from the end of the XIXth century, the term pedology began to function, which is the study of the child (Gr. $\ddot{\alpha} \gamma \omega \gamma o \varsigma$, agagos - a guide) However, since educational activities apply to all age groups, there are also such concepts as: pedagogics (leading children: Gr. $\pi \alpha \tilde{l} \varsigma, \pi \alpha l \delta o ́ \varsigma$, pais, paidos - a child), hebagogy - hebology (leading youth: Gr. " $H \beta \eta$, Hebe - youth, maturity sexual development), andragogy (leading adults: Gr. $\ddot{\alpha} v \eta \dot{\rho} \rho, \not \alpha v \delta \rho o ́ \varsigma$, aner , andros - a man, a husband), gerontagogika (leading the elderly: Gr. $\gamma$ '́ $\rho o v, \gamma \dot{\eta} \rho o v \tau o \varsigma$, geron, gerontos - an old man, old age) and finally anthropagogy and pedagogy (Gr. $\ddot{\alpha} v \theta \rho \omega \pi o \varsigma$, ánthropos - man) - understood as leading a man and learning about his upbringing at every stage of development ${ }^{6}$.

\section{RELIGIOUS EDUCATION}

Religious education has its place in pedagogics. It describes the phenomenon of teaching and learning based on religious sources. Their content and interpretations are determined by the religious community. It refers to the "total impact" aimed at acquiring the competence to interpret everyday life based on religious content, which is why religious education is part of the path of life-long learning. It occurs in the socio-cultural and denominational area and, as a social and individual practice, also assumes that the concepts of education, religion and competences are broadly understood. Religious education has a relational character, therefore it can be implemented in various ways, it takes the form of formal, non-formal and informal education ${ }^{7}$.

6 Comp. Paul Benaych, "Différencier sa pédagogie", en L'essentiel de la pédagogie, ed. Alain Bentolila (Paris: Nathan 2017), 251-274; Oskar Vogelhuber, Geschichte der neueren Pädagogik (München: Ehrenwirth [1955]).

7 Janusz Krysztofik y Anna Walulik, "Edukacja religijna i jej miejsce w ponowoczesności", Studia Katechetyczne 12 (2016): 47; Marian Nowak, "Specyfika, wyzwania, możliwości i perspektywy pedagogiki chrześcijańskiej w Polsce”, en Pedagogika chrześcijańska: tradycja, wspótczesność, nowe wyzwania, ed. Jarosław Michalski y Aldona Zakrzewska (Toruń: Adam Marszałek; Olsztyn: Uniwersytet Warmińsko-Mazurski 2010); Religious Education in Pre-Modern Europe, ed. Ilinca Tanaseanu-Döbler y Marvin Döbler (Leiden y Boston: Brill 2012); Zygmunt Bauman, Riccardo Mazzeo, Conversazioni sull'educazione (Trento: Erickson 2012). 


\section{PEDAGOGICS OF RELIGION}

When speaking about pedagogics, it is impossible not to mention the pedagogics of religion. Simply put, bound by theological sciences, it becomes a scientific discipline that produces basic humanistic and social knowledge as well as applied knowledge ${ }^{8}$. This assumption shows that in this case the subject of pedagogics of religion will be the processes of religious education and socialization that take place in the Church, family and society. The pedagogics of religion will then show the Church as a community that carries out not only missionary and evangelistic tasks, but educational ones as well ${ }^{9}$. It is a normative, empirical and action-oriented discipline.

\section{CATECHESIS}

In literature on this subject, a key term relating to Christian formation appears - catechetics. It is the foundation of the scientific reflection of catechesis (the initiation of Christians - intimacy with Jesus) in its ideal and practical condition: the ideal - it deals with the theological foundations of the message of faith. However, in practical reflection it verifies action with catechetical theories. Catechetics shows the theological correctness of "processes leading Man to faith in God and to receive Jesus Christ and the mission of salvation fulfilled by Him in the Church. On the other hand, the pedagogics of religion seeks to educate in a person the ability to conduct religious reflection on his existence, as well as to acquire the skills of subjective, affirmative and critical processing of religious content and relate them to his own existence. The pedagogics of religion is therefore to inspire actions aimed at developing mental competence, especially understanding and critical thinking. In addition to this, it is to develop competences regarding human existence and its socio-cultural context. These activities are to bring about a rational perception of themselves and the world in the context of tradition and religion"10.

8 Comp. Jürgen Oelkers y Bijan Adl-Amini, Pädagogik, Bildung und Wissenschaft: zur Grundlegung der geisteswissenschaftlichen Pädagogik (Bern y Stuttgart: Verlag Paul Haupt 1982).

9 Comp. Bogusław Milerski, "Pedagogika religii”, en Pedagogika: Subdyscypliny i dziedziny wiedzy o edukacji, ed. Bogusław Śliwerski (Gdańsk: Gdańskie Wydawnictwo Psychologiczne 2010), 265; John Dewey, "Religious education as conditioned by modern psychology and pedagogy", The Religious Association (Chicago: Executive Office of the Association 1903), 60-66.

10 Zbigniew Marek, “Tożsamość pedagogiki religii”, Paedagogia Christiana 1/31 (2013): 98. 


\section{PAIDEA AS THE ARCHETYPE OF PEDAGOGICS, PEDAGOGY AND EDUCATIONAL SCIENCES}

In ancient Greece, the educator was a slave leading a boy (child) to a place of physical exercise, the so-called gimnazjon (Gr. rvpvó $\sigma i o v$ ), around which Hellenic education was organized. It was a set of partially covered buildings intended for exercise in the ancient pentathlon (Gr. $\pi \dot{\varepsilon} v \tau \alpha \theta \lambda o v$, pentathlon: running 192m of an Olympic stadium, long jump, discus throwing, javelin throwing and wrestling), which from $708 \mathrm{BC}$ was an Olympic discipline (it was the beginning of modern athletics and the modern pentathlon). It is also worth mentioning that in addition to the gymnasium, there was also the so-called bar (Gr. $\pi \alpha \lambda \alpha i \sigma \tau \rho \alpha$, palaistra), the Hellenic school of wrestling (from Gr. $\pi \dot{\alpha} \lambda \eta$, pale wrestling). As a rule, it was a rectangular building with four porticos that surrounded a square courtyard. Statues of the athletes' patrons - Heracles and Hermes - were also placed there. In the summer months, exercises were held in the courtyard, hence it could have been an open-air place. More often than not, the bar was part of the gymnasium. The boys trained under the watchful eye of their physical education teacher, the so-called pedotriby (Gr. $\pi \alpha \iota \delta o \tau \rho i \beta \varepsilon \varsigma$, paidotribes - a gymnastics teacher. Bars were to be found in all Greek cities and cult districts where games were organized. Of course there were also private bars. Over time, the physical education model was enriched with Athenian philosophical assumptions, when moral formation and mental development were added to body formation and the forming of a strong character. For this reason, in a short time in Athens paidagogos came to mean a teacher who took his pupil through the basic activities of reading, writing, counting as well as singing and reciting, e.g. the poems of Homer "The Iliad" and "The Odyssey" (Gr.

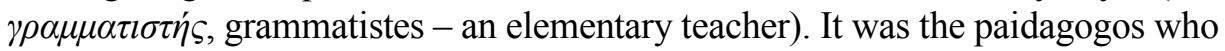
instilled spiritual and moral principles in his pupil, e,g. respecting the elderly. There is no doubt that the sources of pedagogics are in the Hellenistic world, where it was identified with culture (Gr. $\pi \alpha l \delta \varepsilon i \alpha$ - paidea) i.e. the overall upbringing of a man (dealing with both physical and spiritual spheres). Due to this

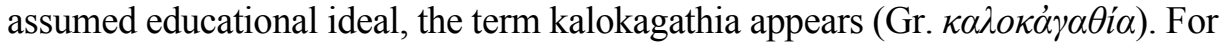
the ancient Greeks the term kalokagatia meant above all ethical perfection. The Greek kalokagathia is derived from the words: kalós kai agathós(Gr. $\kappa \alpha \lambda \grave{o} \varsigma$ $\kappa \dot{\alpha} \gamma \alpha \theta \dot{c} \varsigma$ ), literally - beautiful and good. Such was the understanding of upbringing as to mean a combination of good and beauty. For the first time Aristotle used this word to denote the ideal of raising ephebes in the areas that came under the influence of ancient Greece. In the Roman tradition, the Latin term humanitas was used - humanity in the sense of the best human traits. 
It is worth recalling that for the Greeks - particularly Plato, the creator of the famous educational triad - the values of truth, goodness and beauty were closely connected. This meant that the educational ideal of that time emphasized above all such qualities as manliness, fortitude, courage, sobriety, modesty or civic attitude. Aristotle (384-323 BC) used this motto: "Education is a serious thing - pain must mix with pleasure!" as well as Menander (circa 342-291 BC): He who has never taken a beating - has never received an education. As has already been said, paidagogos was an ancient guardian of a child, at first a slave and later a person fit for the task. Therefore, some knowledge of the profession, information about dealing with children and parenting methods were needed. The paidagogos not only took a child to school but remained his faithful companion, watching out for the child's safety. He was with the child whether at home, at play or travelling. He directly influenced his charge's upbringing and also shaped his pupil's sensitivity. By devoting all his time and attention to him, he could often get attached to him emotionally. A kind of guardianship bond was formed. The New Testament looks at the term paidagogos in a similar way when it speaks of a guide, guardian and educator (cf. 1 Cor 4,15; Gal 3 24-25). In the Gospel according to Saint Matthew $(23,8-10)$ the noun kathegetes appears (Gr. $\kappa \alpha \theta \eta \gamma \eta \tau \dot{s} \varsigma)$ and it has a similar meaning. Bearing in mind the upbringing in the Hellenic tradition, it can be said that Plato was the kathegetes (master-guide) for Aristotle, and Leonidas for Alexander the Great. Clement of Alexandria, a Father of the Church (actually Titus Flavius Clemens; born about 150 in Alexandria, died about 212 in Asia Minor) presents Christ as the Educator and so assumes a specific programme of upbringing. It is worth looking at his work Pedagog, in which he contrasts the assumptions of Christian pedagogics with Greek pedagogics ${ }^{11}$. For Clement, the teacher was no longer a slave in the classical sense, as was the case in the Hellenistic world, but an educator who did not give up his sense of devotion and service: "You call $\mathrm{Me}$ 'Teacher' and 'Lord' and rightly so, for I am. If then I, the Lord and Teacher wash your feet for you, you should also wash each other's feet" (John 13, 13n) because: "(the Son of Man) has not come to be served but to serve and to give His life as a ransom for many" (Mt. 20, 28) ${ }^{12}$. Let this statement be an invitation to the next stage of reflection, the transition from word to action, from theory to practice.

11 Comp. Klemens Aleksandryjski, Wychowawca, trad. Marian Szarmach (Torun: Wydawnictwo Naukowe UMK 2012); James Bowen, A History of Western education. Vol. 1, The ancient world: Orient and Mediterranean (London: Routledge 2003); Werner Jaeger, Paideia : formowanie czlowieka greckiego, trad. Henryk Bednarek y Marian Plezia (Warszawa: Fundacja Aletheia 2001); Stanisław Jankowski, "Greckie tło nowotestamentalnej pedagogii”, en “Wy mnie nazywacie «Nauczycielem» $i$ «Panem» i dobrze mówicie" $(J 13,13)$ : wychowanie w tradycji biblijnej późnożydowskiej $i$ wczesnochrześcijańskiej, ed. Jerzy Bagrowicz y Stanisław Jankowski (Toruń: Wydawnictwo UMK 2010), 71-95.

12 Comp. Pierre Vianin y François-Xavier Amherdt, À l'école du Christ pédagogue: Comment enseigner à la suite du Maître? (Saint-Maurice: Éditions Saint-Augustin 2011. 


\section{ARS EDUCANDI}

The difference between pedagogy and pedagogics can be expressed as follows: the first is a set of means and a method of education used by teachers which refer to the practice of "the art of education". While pedagogics is a theoretical and scientific reflection on educational practice. Currently, the concept of pedagogy also refers to an education paradigm which can take the form of a pedagogical doctrine, an educational ideology or a hidden education programme (e.g. schools) ${ }^{13}$. At this point, a proper association with Aristotle's thought may

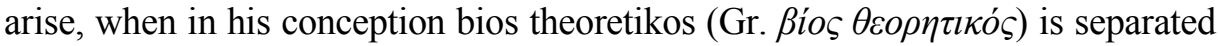
from bios praktikos (Gr. Bís $\pi \rho \alpha \kappa \tau \imath \kappa o ́ \varsigma)$. Thus a good educator differs from a bad one only in the number of mistakes that he makes.

In the richness of the content of the terms from the education and Hellenic culture that has been cited, it is easy to notice that the concept of pedagogy (Gr. $\pi \alpha l \delta \varepsilon i \alpha$ ) is close to the modern term "the art of education" (Gr. $\pi \alpha l \delta \alpha \gamma \omega \gamma l \kappa \eta \dot{\tau} \tau \varepsilon \chi v \eta$ - paidagogike techne; Lt. ars educandi; ars artium et scientia scientiarum) Wanting to avoid terminological traps and related errors, it is worth remembering that the "term 'pedagogy' is a complexed concept. It refers to the entire teaching and upbringing process and contains, as we can read in the Pedagogical Encyclopedia of XXIst Century, four basic references: to the person being guided (headed), the scholar, i.e. the pupil; to the supervisor - teacher and educator; to the process itself; and to the subject of teaching and upbringing"14. The sources of the Greek term pedagogia not only cover all of the exertions taken around the child being raised, but also the educational activities and effects. Pedagogy is primarily associated with a person and is of a total nature, covering all dimensions of the human person, as well as actions taken to form them. Pedagogy means a work of education and a set of related activities and skills ${ }^{15}$. We can talk here about home, school, church and national pedagogy ${ }^{16}$. Literature on the subject includes, for example, the pedagogy of faith, biblical pedagogy, the pedagogy of God, the pedagogy of St. John Paul II or, for example, Salesian pedagogy.

Reflecting on the theoretical and practical impact on the pupil, it is worth looking at Janina Kostkiewicz's analysis who, as an editor, devotes three

13 Comp. Pedagogika : leksykon PWN, ed. Bogusław Milerski y Bogusław Śliwerski (Warszawa: Wydawnictwo Naukowe PWN 2000), 144.

14 Agnieszka Wielgus, "Personalistyczne aspekty pedagogii ignacjańskiej”, en Personalistyczny wymiar filozofii wychowania, ed. Anna Szudra y Katarzyna Uzar (Lublin: Wydawnictwo Naukowe KUL 2009), 293.

15 Sonia M. Gonzalez-Iglesias y Carmen de la Calle Maldonado, "El acompañamiento educativo, una mirada ampliada desde la antropología personalista", Scientia et Fides 1 (2020): 183-203.

16 Comp. Cichosz, Pedagogia wiary we współczesnej szkole katolickiej, 137. 
prominent volumes to the pedagogies of religious congregations. Listing the whole range of Catholic educational systems appearing throughout history, we meet, for example, Jesuit pedagogy, the previously mentioned Salesian pedagogy, and the Salesian Sisters' pedagogy, that of the Sisters of Nazareth, and the Piarists and also Franciscan pedagogy, St. Vincent a Paulo's pedagogy and many more. The names already suggested indicate the content of the work they carry out and their numerous connotations. The Christian paidea wants to take Man to a higher spiritual level, without denying the values of the ancient Greek tradition (beauty - goodness - truth) maintains that their faith fulfils the education mission to humanity to a greater degree than before. Greek paideia, thanks to Christianity, was renewed, transformed and completed, hence, e.g. the already mentioned Clement of Alexandria argued that Christianity offered humanity an education which fulfills God's providence. This belief was followed by other Church Fathers, especially the Fathers of Cappadocia - Basil of Caesarea and Gregory of Nazianzus. They distinguished between the Greek and Christian paideia (paidee). The first included all works of Greek literature, while the second was the Bible. For Gregory, Christian upbringing consists in shaping man on Christ's model. (Lt. de perfecta forma Christiani). This is evident in the way in which Gregory of Nazianzus shows the Bible as the highest authority ${ }^{17}$. We are facing the main thought of all antiquity. Pedagogy is not just an educational theory, but essentially something far more than ordinary humanism or philanthropy.

\section{PRACTICAL IMPLICATIONS}

Since pedagogics should be understood as the science of upbringing, it is difficult to talk about one model today, because both science and upbringing are ambiguous terms. In this way, only in pedagogics itself can be mentioned some basic concepts that are in a natural and close relationship with philosophy and the values that flow from it. Philosophy - writes Tadeusz Gadacz - "remained in various relationships with pedagogics in the twentieth century. Some twentieth century philosophers were at the same time outstanding educators. Pedagogics itself drew strong inspiration from philosophy"18. Bogusław Śliwerski, when studying contemporary trends and theories of upbringing, indicates as many as seventeen models ${ }^{19}$. Among these are those trends and theories which correspond

17 Comp. Dave Bland, Proverbs : Ecclesiastes : Song of Solomon (Joplin: College Press Publishing Company 2002).

18 Tadeusz Gadacz, Historia filozofii XX wieku : nurty. Vol. 1, Filozofia życia, pragmatyzm, filozofia ducha (Kraków: Wydawnictwo Znak 2009), 49.

19 Comp. Bogusław Śliwerski, Wspótczesne teorie i nurty wychowania (Kraków: Oficyna Wydawnicza Impuls 2015). 
with Christian thought, and others that are based on completely different references. The difference in modern education systems is primarily due to philosophical assumption and subsequent consequences. Ideological ideas in contemporary Polish pedagogics have developed essentially in two directions: (1) Christian, in which the sent love dominates in the spiritual dimension, based on the model of God's love for Man (the so-called "do" freedom) and (2) liberal, which prefers the pursuit of unrestricted cultural progress and personal freedom (the so-called "freedom" from $)^{20}$.

The above analyses constitute the basic context for perceiving pedagogy (Gr. $\pi \alpha l \delta \alpha \gamma \omega \gamma i \alpha$ - paidagogia). While pedagogics concerns the theory of education, pedagogy makes full use of the ancient paideia (Gr. $\pi \alpha l \delta \varepsilon i \alpha$ - paideia, Lt. educatio), which in the Greek world meant the comprehensive formation of a young Greek. The concept introduced by the Sophists (VI-V centuries BC) meant above all an education in grammar, rhetoric and dialectics. Paidea (paideia) - as has already been said - was understood as comprehensive education, formation, training and finally discipline. This form appears thirteen times in the New Testament, and it is also present in both the Greek and Semitic tradition. The content of paidea is particularly evident in pedagogical Jewish customs in which corporal punishment and mnemotechnical methods were a natural means of motivating a child to learn and behave properly. The basics of teaching and upbringing was the Bible - the texts that it contained were an object for learning to read and write. Its writings became a kind of guide in the fields of geography and history, a textbook of psychology and an educational model. The biblical psalms formed the basis of singing and music. Biblical pedagogy, drawing on the wisdom of the Ten Commandments, was a model for the relationship between parents and children ${ }^{21}$. First of all, there was the commandment that clearly indicated unconditional obedience and respect for parents and observance of the so-called Christian home rules (cf. Eph 6: 1-4; Prov 3: 11; 2,2) was a condition for a good long life on earth (cf. Eph 6:2; Ex 20: 12; Deut 5: 16) ${ }^{22}$.

20 Comp. Cichosz, Wychowanie chrześcijańskie wobec postmodernistycznej prowokacji, 199-209; Current research problems of Polish education, ed. Joanna Wierzejska, Oresta Karpenko y Renata Franczak (Lublin: Maria Curie-Skłodowska University Press 2017), 259, ln. 40-42. Sara Gallardo and Elena Martínez, ""Lo propio del hombre". Apuntes de antropología ratzingeriana”, Cauriensia 15 (2020): $385-404$.

21 Sławomir Tykarski, "The evolution of modern marriage : from community to individualization : theological reflection", Cauriensia 14 (2019): 581-592.

22 Comp. Jan Kochel y Zbigniew Marek, Pedagogia biblijna $w$ katechezie (Kraków: Wydawnictwo WAM 2012), 64; Zdzisław Pawłowski, "To Eat or Not to Eat : Politics, Religion, and Eating in 1 Kings 13", Biblica et Patristica Thoruniensia 12 (2019) 1: 79; Wojciech Pikor, "Jaki paradygmat życia rodzinnego w narracji o Abrahamie?”, Biblica et Patristica Thoruniensia 13 (2020) 1: 109-110. 
An eloquent example of the implementation of the above assumptions reaching both to the Hellenic and Biblical models of education - is the pedagogy of St. John Paul II, which as the main purpose of education, extending to the whole life of a man (the subject of education), indicates human and Christian maturity. Referring to the Pope's words, the essence of upbringing is "that a man may become more a man - that a man may be more and not only have more; so that through everything a man has, what a man possesses, a man can become a man more fully - that is that a man can also be more not only with others, but also for others"23. The real development of a man is confirmed, among other things, thanks to personal relations with other people, because each "man by nature is a social being and in his structure lies the basis of various interpersonal references" 24 . Saint John Paul II repeatedly showed us that in order to lead a man to the educational ideal, it is necessary to understand "who the man is in himself and what is his ultimate purpose" ${ }^{125}$, remembering at the same time that every individual requires individual treatment. Education in the pedagogy of St. John Paul II is about "humanizing" man, learning to be human ${ }^{26}$. An important role in the implementation of this assumption is played by the co-operation of the educator and the one being educated, because only a proper educator is able to lead his pupil to the goal that is well known to him and to which he is heading. St. John Paul II's anthropological foundations of education arise from the message of the uniqueness and individuality of a man, therefore in the process of guiding a student (pedagogical company) it is necessary to use the achievements of psychology, didactics and pedagogics. The aim of such is the harmonious development of innate properties and the shaping of conscience (responsibility for one's own actions).

The foundation of St. John Paul II's pedagogy is the assumption that a man is a person endowed with dignity and that he has rights arising from the status of a child of God, so he cannot be "an object or instrument in the hands of another

23 Jan Paweł II, "Przemówienie w siedzibie Organizacji Narodów Zjednoczonych ds. Oświaty, Nauki i Kultury (UNESCO). Paryż, 2 czerwca 1980”, en Stużyć wzrastaniu w prawdzie i miłości: wybór dokumentów Kościoła na temat szkoły katolickiej $i$ wychowania, ed. Janusz Poniewierski (Kraków: Wydawnictwo AA 2009), 202.

24 Marian Śnieżyński, “Pedagogika Jana Pawła II”, Wychowawca 10 (2003): 14-15.

25 Jan Paweł II, "Poszukiwanie prawdy i kształtowanie młodych do prawdziwej wolności człowieka. Przemówienie na uniwersytecie, Padwa, 12.09.1982", en John Paul et al., Wiara i kultura. Dokumenty, przemówienia, homilie (Rzym y Lublin: Redakcja Wydawnictw KUL 1988), 162-163.

26 Comp. idem, "Przyszłość człowieka to sam człowiek. W czasie mszy świętej dla rodzin. Braga - Monte Sameiro, Portugalia, 15.05.1982", en Rodzina w nauczaniu Jana Pawła II: antologia wypowiedzi, ed. Józef Żukowicz et al. (Kraków: Wydawnictwo Apostolstwa Modlitwy 1990), 91; The Pedagogy of God : Its Centrality in Catechesis and Catechist Formation, ed. Caroline Farey, Waltraud Linnig y M. Johanna Paruch (Steubenville: Emmaus Road Publishing 2011), 26-27. 
person, even if he held the most important political, social or economic offices" 27 . A pupil discovering his own dignity in meeting another person (especially in peace with Christ), becomes a person ${ }^{28}$, and receiving Christ enables the believer to reveal God's plan of salvation and to accept the main truth of the professed faith $^{29}$. It enables him to discover his own vocation to co-operate with God to achieve the ultimate goal. Jesus, placed at the centre of the education process, enables man to constantly deepen his moral attitude, which is the perfection of a human being ${ }^{30}$. St. John Paul II's pedagogy affirms that a man who is in his full upbringing should become a reflection of the ideal which is God-Man, for it is impossible to understand who a man is without referring to the image and likeness in which he was created (anthropology and divine genealogy).

In the light of the above analyses, it should be noted that in educational theory and practice, pedagogy and pedagogics differ significantly, although this difference is not always noticed. An example is volume I of the scientific review dedicated to the "Catholic Pedagogy of Religious Congregations" by Janina Kostkiewicz, in which we read: "It is noteworthy to accept for analysis this scientific category, which is called pedagogy, therefore a category related to both theoretical assumptions, activities practically coupled not only with religious education but also with moral education (civic, patriotic and social) aesthetic education, health education, care, prevention, therapy - these areas have great importance in pedagogical practice today. It is remarkable, that the analyses of the pedagogics of Catholic religious congregations are recognized in both a historical and contemporary dimension (...). The congregations' pedagogies with their rich historical references and contemporary relevance constitute (may constitute) valuable sources of constructive reflection in current pedagogics seeking such reflection in a situation of imbalance, ambivalence, uncertainty, nebulae of concepts and views, and relativism of views" ${ }^{\prime 31}$. It should be assumed that the phrases used above are referred to as "pedagogy" and the pedagogics of Catholic

27 Zbigniew Zarembski, "Pedagogia wiary w nauczaniu papieża Jana Pawła II", Ateneum Kapłańskie 142(2004)2, 227-228.

28 Comp. Karol Wojtyła, Miłość $i$ odpowiedzialność (Lublin: Wydawnictwo Towarzystwa Naukowego KUL 1986), 54.

29 Comp. John Paul II, Redeemer of Man: Encyclical Redemptor Hominis (London: Veritas 1979), 10.

30 Comp. Karol Wojtyła, Ocena możliwości zbudowania etyki chrześcijańskiej przy założeniach systemu Maksa Schelera (Lublin: Towarzystwo Naukowe KUL 1959), 87; Zarembski, "Pedagogia wiary w nauczaniu papieża Jana Pawła II", 229.

31 Joanna Kostkiewicz, Pedagogie katolickich zgromadzeń zakonnych. Vol. 1, Historia $i$ współczesność (Kraków: Oficyna Wydawnicza Impuls 2012), IV. 
religious congregations is only an unfortunate editorial sweep not a deliberate attempt.

Many similar examples can be pointed out in literature on this subject. They seem to be about trivial things but in reality, when theory becomes practice, they are serious matters. The theory of pedagogics and its implementation are two completely different matters. Guiding a student and accompanying him on the path of harmonious growth - in body, mind and spirit - must always be treated as a fundamental task, because it becomes a kind of realization of the virtual world.

\section{CONCLUSION}

Finally, answering the question posed in the title: pedagogics or pedagogy?, it should be said that it is not always possible to distinguish precisely the key concepts - pedagogics or pedagogy especially when they are derived from the noun "pedagog" or the adjective "pedagogical" and joined to "action" (theoretical or practical). Hence, the pedagog and the pedagogical process applies to both pedagogics and pedagogy. When speaking of theoretical and philosophical thought, the concept of pedagogics is used rather than pedagogy. Terminological inconsistency, both theoretical and practical, may prove to be fatal. Some authors do not place too much attention to this fact. Confirmation of this can be found in the titles of some publications or in the incorrect synonymous use of terms. There is a difference between pedagogy and pedagogics. Awareness and terminological clarity appear to be at the root of ambiguities arising in this field. Although both concepts come from the Greek paideia and are closely related, the accent that is placed on education is different. This is demonstrated by both the presentation of the history of education and contemporary thought. This is perfectly confirmed by, for example, Janina Kostkiewicz, who rightly entitled one of her last books, Directions and Concepts of Catholic Pedagogics in Poland 1918-193932. Ancient civilization associated upbringing with culture, which later accepted Christianity. In Latin culture - arising from three sources: Greek philosophy, Roman law and the Christian religion (Acropolis, Quirinal and Golgotha) - pedagogics is understood as a theory of upbringing and teaching, being a conscious and purposeful education activity, but pedagogy is rather a system and whole activities: skills and educational effects. In view of the above, it can be stated that pedagogics will as a rule be question-orientated - which one? (philosophical and anthropological scientific reflection on upbringing especially at a theoretical

32 Comp. eadem, Kierunki i koncepcje pedagogiki katolickiej w Polsce 1918-1939 (Kraków: Oficyna Wydawnicza Impuls 2017). 
level), and pedagogy on the question - whose? (it is about both the person and the practice of integral interaction). If pedagogics is treated as a theory of upbringing and teaching (conscious and intentional upbringing) then the term should be consistently referred to as a set of means and methods of teaching and upbringing. However, when pedagogics is understood as theoretical and practical knowledge about upbringing and teaching, then pedagogia will already be a set of educational methods which are used by teachers and educators. Such is the definition and juxtaposition of the analysed concepts: pedagogics and pedagogy - allow pedagogics to be treated as a science whose subject is various types of pedagogy (educational practice), i.e. leading children and youth, as well as influencing adults.

\section{BIBLIOGRAPHICAL REFERENCES}

Bauman, Zygmunt y Mazzeo Riccardo. Conversazioni sull'educazione. Trento: Erickson, 2012.

Benaych, Paul. "Différencier sa pédagogie". En L'essentiel de la pédagogie, editado por Alain Bentolila, 251-274. Paris: Nathan, 2017.

Bland, Dave. Proverbs, Ecclesiastes, Song of Solomon. Joplin: College Press Publishing Company, 2002.

Bowen, James, A History of Western education. 1, The ancient world: Orient and Mediterranean. London: Routledge, 2003.

Brzezinski, Zbigniew. Between Two Ages. New York: The Viking Press, 1970.

Cichosz, Wojciech. "Między nagrodą a karceniem: rola systemów motywacyjnych w edukacji”. Gdyński Kwartalnik Oświatowy 1 (2004): 6468.

Cichosz, Wojciech. Metodologia. Elementarz Studenta. Gdańsk: Zakłady Graficzne im. KEN SA, 2000.

Cichosz, Wojciech. Możliwości dialogu wychowania chrześcijańskiego ze współczesna edukacja polska. Pelplin: Bernardinum, 2013.

Cichosz, Wojciech. Pedagogia wiary we współczesnej szkole katolickiej. Warszawa: Wydawnictwo TYPO2, 2010.

Cichosz, Wojciech. Wychowanie chrześcijańskie wobec postmodernistycznej prowokacji. Gdańsk: Zakłady Graficzne im. KEN SA, 2001.

Cichosz, Wojciech. "Quo vadis Akademia? Kulturowa rekonfiguracja nauki", Studia Gdańskie 38 (2016): 201-213.

Cichosz, Wojciech. "Pedagogia czy pedagogika? Recepcja aksjologii terminologicznej”. En Pedagogika rodziny : podejście systemowe. vol. 1: Familiologia, editado por Marek Marczewski, Roman Gawrych, Danuta Opozda, Tadeusz Sakowicz y Adam Solak, 123-140. Gdańsk: Wyższa Szkoła Społeczno-Ekonomiczna, 2016. 
Wierzejska, Joanna, Karpenko Oresta y Franczak, Renata. Current research problems of Polish education. Lublin: Maria Curie-Skłodowska University Press, 2017.

Dewey, John. "Religious education as conditioned by modern psychology and pedagogy", The Religious Association. Chicago: Executive Office of the Association (1903): 60-66.

Education of tomorrow. Contemporary education and is contexts, editado por Kazimierz Denek. Sosnowiec: Wyższa Szkoła Humanitas, 2011.

Gadacz, Tadeusz. Historia filozofii XX wieku : nurty. Vol. 1, Filozofia życia, pragmatyzm, filozofia ducha. Kraków: Wydawnictwo Znak, 2009.

Gallardo, Sara and Elena Martínez, "Lo propio del hombre". Apuntes de antropología ratzingeriana". Cauriensia 15 (2020): 385-404.

Gonzalez-Iglesias, Sonia M. y Calle Maldonado de la, Carmen. "El acompañamiento educativo, una mirada ampliada desde la antropología personalista". Scientia et Fides 1 (2020): 183-203.

Jaeger, Werner. Paideia. Formowanie czlowieka greckiego. Traducido por Henryk Bednarek y Marian Plezia. Warszawa: Fundacja Aletheia, 2001.

Jan Paweł II. "Przemówienie w siedzibie Organizacji Narodów Zjednoczonych ds. Oświaty, Nauki i Kultury (UNESCO). Paryż, 2 czerwca 1980”. En Stużyć wzrastaniu $w$ prawdzie i miłości: wybór dokumentów Kościoła na temat szkoły katolickiej $i$ wychowania, editado por Janusz Poniewierski, 201-205. Kraków: Wydawnictwo AA, 2009.

Jan Paweł II. Redeemer of Man: Encyclical Redemptor Hominis. London: Veritas, 1979.

Jan Paweł II. "Poszukiwanie prawdy i kształtowanie młodych do prawdziwej wolności człowieka. Przemówienie na uniwersytecie, Padwa, 12.09.1982". En Wiara i kultura. Dokumenty, przemówienia, homilie, editado por Marian Radwan, Stefan Wylężek y Teresa Gorzkula, 162-163: Rzym y Lublin: Redakcja Wydawnictw KUL, 1988.

Jan Paweł II. "Przyszłość człowieka to sam człowiek. W czasie mszy świętej dla rodzin. Braga - Monte Sameiro, Portugalia, 15.05.1982”. En Rodzina w nauczaniu Jana Pawła II: antologia wypowiedzi, editado por Józef Żukowicz, Czesław Drążek y Ryszard Dudek, 89-92. Kraków: Wydawnictwo Apostolstwa Modlitwy, 1990.

Jankowski, Stanisław. "Greckie tło nowotestamentalnej pedagogii". En "Wy mnie nazywacie «Nauczycielem» $i$ «Panem» $i$ dobrze mówicie" $(J$ 13, 13) : wychowanie w tradycji biblijnej późnożydowskiej i wczesnochrześcijańskiej, editado por Jerzy Bagrowicz y Stanisław Jankowski, 71-95. Toruń: Wydawnictwo UMK, 2010.

Klemens Aleksandryjski. Wychowawca. Traducido por Marian Szarmach. Toruń: Wydawnictwo Naukowe UMK, 2012.

Kochel, Jan y Marek, Zbigniew. Pedagogia biblijna w katechezie. Kraków: Wydawnictwo WAM, 2012. 
Kostkiewicz, Joanna. Kierunki i koncepcje pedagogiki katolickiej w Polsce 19181939. Kraków: Oficyna Wydawnicza Impuls, 2017.

Kostkiewicz, Joanna. Pedagogie katolickich zgromadzeń zakonnych. Vol. 1, Historia $i$ wspótczesność. Kraków: Oficyna Wydawnicza Impuls, 2012.

Krysztofik, Janusz y Walulik, Anna. "Edukacja religijna i jej miejsce w ponowoczesności”. Studia Katechetyczne 12 (2016): 35-50.

Marek, Zbigniew. "Tożsamość pedagogiki religii”, Paedagogia Christiana 1/31 (2013): 94-105.

Milerski, Bogusław. "Pedagogika religii". En Pedagogika: Subdyscypliny $i$ dziedziny wiedzy o edukacji, editado por Bogusław Śliwerski, 261-277. Gdańsk: Gdańskie Wydawnictwo Psychologiczne, 2010.

Nowak, Marian. "Specyfika, wyzwania, możliwości i perspektywy pedagogiki chrześcijańskiej w Polsce”. En Pedagogika chrześcijańska: tradycja, współczesność, nowe wyzwania, editado por Jarosław Michalski y Aldona Zakrzewska, 13-35. Toruń: Adam Marszałek; Olsztyn: Uniwersytet Warmińsko-Mazurski, 2010.

Oelkers, Jürgen y Adl-Amini, Bijan. Pädagogik, Bildung und Wissenschaft: zur Grundlegung der geisteswissenschaftlichen Pädagogik. Bern y Stuttgart: Verlag Paul Haupt, 1982.

Oviedo-Torró, Lluis. "Meaning and Religion: Exploring Mutual Implications", Scientia et Fides 7/1 (2019): 25-46.

Pawłowski, Zdzisław. "To Eat or Not to Eat : Politics, Religion, and Eating in 1 Kings 13". Biblica et Patristica Thoruniensia 12 (2019) 1: 71-89.

Pedagogika. Leksykon PWN, editado por Bogusław Milerski y Bogusław Sliwerski. Warszawa: Wydawnictwo Naukowe PWN, 2000.

Pikor, Wojciech. "Jaki paradygmat życia rodzinnego w narracji o Abrahamie?". Biblica et Patristica Thoruniensia 13 (2020) 1: 105-126.

Religious Education in Pre-Modern Europe, editado por Ilinca Tanaseanu-Döbler y Marvin Döbler. Leiden y Boston: Brill, 2012.

Śliwerski, Bogusław. Współczesne teorie i nurty wychowania. Kraków: Oficyna Wydawnicza Impuls, 2015.

Śnieżyński, Marian. “Pedagogika Jana Pawła II”. Wychowawca 10 (2003): 14-17.

The Pedagogy of God : Its Centrality in Catechesis and Catechist Formation, editado por Caroline Farey, Waltraud Linnig y M. Johanna Paruch. Steubenville: Emmaus Road Publishing, 2011.

Tykarski, Sławomir. "The evolution of modern marriage: From community to individualization. Theological reflection". Cauriensia 14 (2019): 581-592.

Vianin, Pierre y Amherdt, François-Xavier. À l'école du Christ pédagogue : comment enseigner à la suite du Maître?. Saint-Maurice: Éditions SaintAugustin, 2011.

Vogelhuber, Oskar. Geschichte der neueren Pädagogik. München: Ehrenwirth, [1955]. 
Wielgus, Agnieszka. "Personalistyczne aspekty pedagogii ignacjańskiej”. En Personalistyczny wymiar filozofii wychowania, editado por Anna Szudra y Katarzyna Uzar, 293-302. Lublin: Wydawnictwo Naukowe KUL, 2009.

Wojtyła, Karol. Miłość i odpowiedzialność. Lublin: Wydawnictwo Towarzystwa Naukowego KUL, 1986.

Wojtyła, Karol. Ocena możliwości zbudowania etyki chrześcijańskiej przy założeniach systemu Maksa Schelera. Lublin: Towarzystwo Naukowe KUL, 1959.

Zarembski, Zbigniew. "Pedagogia wiary w nauczaniu papieża Jana Pawła II". Ateneum Kaptańskie 142 (2004) 2: 221-237.

\author{
Wojciech Cichosz \\ Nicolaus Copernicus University \\ Wydział Teologiczny \\ ul. Gagarina 37 \\ Toruń, Polonia \\ https://orcid.org/0000-0003-0839-2179
}

